\title{
PENGARUH KOMPENSASI, KEPUASAN KERJA, MOTIVASI KERJA DAN GAYA KEPEMIMPINAN TERHADAP KINERJA KARYAWAN
}

\author{
Rahadian Fernanda \\ Prodi Akuntansi Universitas Negeri Yogyakarta \\ Rahadianfernanda@yahoo.co.id \\ Endra Murti Sagoro \\ Staf Pengajar Jurusan Pendidikan Akuntansi Universitas Negeri Yogyakarta
}

\begin{abstract}
Abstrak : Pengaruh Kompensasi, Kepuasan Kerja, Motivasi Kerja Dan Gaya Kepemimpinan Terhadap Kinerja Karyawan. Penelitian ini bertujuan untuk mengetahui Pengaruh Kompensasi, Kepuasan Kerja, Motivasi Kerja dan Gaya Kepemimpinan terhadap Kinerja Karyawan pada UMKM di desa Wisata Bobung Gunungkidul Yogyakarta. Penelitian ini menggunakan jenis penelitian survey. Sampel dalam penelitian ini adalah sebanyak 119 karyawan. Teknik pengumpulan data dalam penelitian ini mengunakan kuesioner dan observasi. Uji coba instrumen menggunakan uji normalitas, uji linieritas, uji multikolinieritas, uji heteroskedatisitas. Metode analisis data yang digunakan analisis regresi linear sederhana dan analisis regresi linear berganda. Hasil Penelitian menunjukkan bahwa: (1) Kompensasi berpengaruh positif terhadap Kinerja Karyawan. (2) Kepuasan Kerja berpengaruh positif terhadap Kinerja Karyawan. (3) Motivasi Kerja berpengaruh positif terhadap Kinerja Karyawan. (4) Gaya Kepemimpinan berpengaruh positif terhadap Kinerja Karyawan. (5) Kompensasi, Kepuasan Kerja, Motivasi Kerja dan Gaya Kepemimpinan secara bersama-sama berpengaruh positif terhadap Kinerja Karyawan.
\end{abstract}

Kata kunci: Persepsi Mahasiswa, Konflik Kepentingan, Kesenjangan Anggaran, Anggaran Partisipatif

\begin{abstract}
The Influence Of Compensation, Job Satisfaction, Job Motivation And
Leadership Style On The Employees Performance. The purposes of this research are to determine the influence of compensation, job satisfaction, job motivation and leadership style on the employees performance on SMEs in Bobung tourism village Gunungkidul Yogyakarta. This research is a type of survey research. The sample on this research is 119 employees. The data collection method used is questionnaire and observation. The test instrument is using normality test, linearity test, multicollinearity test, and heteroscedasticity test. Data analysis method used in this researh is simple linear regression analysis and multiple linear regression analysis. Based on the results of data analysis, the inferences are : (1) Compensation has a positive influence on the employees performance. (2) Job satisfaction has a positive influence on employees performance (3) Job motivation has a positive influence on the employees performance. (4) Leadership style has a positive influence on the employees performance. (5) Compensation, job satisfaction, job motivation and leadership style has a positive influence on the employees performance.
\end{abstract}

Keywords: Employees performance, Job Satisfaction, Job Motivation, Leadership Style

\section{PENDAHULUAN}

Saat ini keberadaan Usaha Mikro, Kecil dan Menengah (UMKM) di negaranegara berkembang dapat dikatakan sebagai tulang punggung perekonomian negara. Meski para UMKM ini memiliki beberapa keterbatasan namun pada kenyataannya mereka mampu bersaing dengan perusahaanperusahaan lain. Persaingan bisnis di Indonesia dari tahun ke tahun semakin meningkat, hal inilah yang mendorong para pelaku UMKM untuk selalu membuat 


\section{JURNAL NOMINAL / VOLUME V NOMOR 2 / TAHUN 2016}

konsumen mereka merasa puas terhadap produk dan pelayanan mereka. Selain itu perusahaan juga harus mempunyai sumber daya yang cukup baik seperti sumber daya alam, sumber daya modal maupun sumber daya manusia. Ketiga sumber daya tersebut harus mampu dikelola dengan baik oleh perusahaan secara efektif dan efisien demi tercapainya tujuan perusahaan.

Sumber daya manusia merupakan salah satu sumber daya yang memiliki peran paling penting dan dominan dalam setiap perusahaan, karena walaupun berlimpahnya sumber daya alam dan tersedianya modal yang cukup apabila semua hal tersebut tidak dapat dikelola dengan dukungan sumber daya manusia yang baik maka perusahaan tidak akan berjalan dengan baik. Peningkatan kinerja karyawan perlu dilakukan untuk memaksimalkan peranan tenaga kerja di dalam perusahaan.

Industri topeng kayu di Dusun Bobung Gunungkidul Yogyakarta merupakan salah satu UMKM yang menjadi unggulan di Kabupaten Gunungkidul. Industri kerajinan topeng kayu di Dusun Bobung berawal pada tahun 1955 dan sampai sekarang masih berjalan. Namun seiring berkembangnya zaman tidak hanya kerajinan topeng kayu yang dikerjakan namun sudah mengarah ke pembuatan kerajinan batik kayu yang telah dimulai pada tahun 1980-an. Kegiatan industri topeng kayu ini berkaitan dengan kreasi, produksi dan distribusi produk yang dihasilkan oleh tenaga pengrajin yang berawal dari desain awal sampai dengan proses penyelesaian produknya. Walaupun sudah memberikan sumbangan terhadap pendapatan daerah secara signifikan dalam kenyataannya industri kreatif masih mengalami kendala-kendala yang dapat menghambat berkembangnya industri tersebut dalam masyarakat.

Ada beberapa kendala yang tengah dihadapi oleh industri topeng kayu tersebut, diantaranya yaitu masalah kinerja karyawannya yang dapat dilihat dari kompensasi yang masih rendah baik materi maupun non materi, kepuasan kerja yang rendah yang dapat dilihat dari tingkat disiplin karyawan yang rendah, motivasi kerja yang dapat dilihat dari masih terdapat karyawan yang tidak bersedia untuk lembur, berinovasi dan belajar, gaya kepemimpinan yang dapat dilihat dari partisipasi karyawan yang rendah dalam pengambilan keputusan perusahaan.

Kinerja merupakan hasil proses pekerjaan yang dicapai oleh karyawan dalam melakukan pekerjaannya dan tanggung jawab yang diberikan kepadanya. Kinerja adalah sesuatu yang dapat dicapai seseorang atau kelompok orang dalam organisasi, sesuai dengan wewenang dan tanggung jawab masing-masing dalam rangka upaya mencapai tujuan perusahaan bersangkutan secara legal, tidak melanggar hukum, dan 


\section{JURNAL NOMINAL / VOLUME V NOMOR 2 / TAHUN 2016}

sesuai moral dan etika (Suyadi Prawirosentono, 1999: 64).

Kompensasi merupakan segala sesuatu yang diterima karyawan sebagai balas jasa untuk kerja mereka (Hani Handoko, 2010:155). Menurut Bejo Siswanto dalam Abdul Halim (2003: 223) kompensasi adalah imbalan jasa yang diberikan perusahaan kepada tenaga kerja karena telah memberikan sumbangan tenaga dan pikiran demi kemajuan dan kontinuitas perusahaan dalam rangka mencapai tujuan yang telah ditetapkan baik dalam jangka pendek maupun jangka panjang.

Menurut Mangkunegara (2009: 117) kepuasan kerja adalah suatu perasaan yang menyokong atau tidak menyokong diri pegawai yang berhubungan dengan pekerjaannya maupun dengan kondisi dirinya. Sedangkan Handoko (2002: 193) menyatakan bahwa kepuasan kerja (job statisfaction) adalah keadaan emosional yang menyenangkan atau tidak menyenangkan dengan mana karyawan memandang pekerjaan mereka.

Menurut Malayu S.P Hasibuan (2005: 143), motivasi berasal dari kata latin movere yang berarti dorongan atau pemberian daya penggerak yang menciptakan kegairahan kerja seseorang agar segala daya upayanya untuk mencapai kepuasan. Motivasi (motivasion) dalam manajemen hanya ditujukan pada sumber daya manusia umumnya dan bawahan khususnya.
Pentingnya motivasi karena motivasi adalah hal yang menyebabkan, menyalurkan, dan mendukung prilaku manusia, supaya mau bekerja giat dan antusias mencapai hasil yang optimal.

Menurut Sudarwan Danim (2004: 56) Kepemimpinan adalah setiap perbuatan yang dilakukan oleh individu atau kelompok untuk mengkoordinasi dan memberi arah kepada individu atau kelompok yang tergabung didalam wadah tertentu untuk mencapai tujuan yang telah ditetapkan sebelumnya. Menurut Malayu S.P Hasibuan (2008: 170) Kepemimpinan adalah cara seseorang pemimpin mempengaruhi perilaku bawahan, agar mau bekerja sama dan bekerja sevara produktif untuk mencapai tujuan organisasi.

\section{METODE PENELITIAN}

Jenis Penelitian

Penelitian ini termasuk penelitian survey dengan menggunakan kuesioner. Penelitian survey adalah penelitian yang mengambil sampel dari satu populasi dan menggunakan kuesioner sebagai alat pengumpul data yang pokok (Suharsimi Arikunto, 2007: 265).

\section{Waktu dan Tempat Penelitian}

Penelitian ini dilaksanakan di Desa wisata Bobung Gunungkidul Yogyakarta. Waktu Penelitian dilaksanakan pada bulan Februari 2016 hingga bulan Juli 2016. 


\section{JURNAL NOMINAL / VOLUME V NOMOR 2 / TAHUN 2016}

\section{Subjek Penelitian}

Populasi dalam penelitian ini adalah semua karyawan pada UMKM di desa Wisata Bobung Gunungkidul Yogyakarta yang berjumlah 170 orang yang terbagi kedalam 10 Sentra kerajinan topeng kayu. Pengambilan sampel mengunakan metode Proportionate Random Sampling yaitu pengambilan sampel yang dilakukan dengan mengambil wakil dari wilayah yang terdapat dalam populasi (Suharsimi Arikunto, 2010: 112). Kemudian dilakukan teknik Simple Random Sampling yaitu setiap elemen dalam populasi mempunyai kesempatan yang sama untuk dipilih, pengambilan sampel dapat dilakukan dengan mengambil sampel secara acak dari unit pemilihan sampel (Kuncoro, 2003: 112).

\section{Prosedur}

Prosedur yang digunakan dalam penelitian ini yaitu dengan cara menyebarkan kuesioner atau daftar pertanyaan kepada karyawan pada UMKM di desa Wisata Bobung Gunungkidul Yogyakarta.

\section{Data, Instrumen dan Teknik}

\section{Pengumpulan Data}

\section{Data}

Data yang digunakan dalam penelitian ini adalah data primer yang diperoleh secara langsung dari lapangan. Instrumen yang digunakan dalam penelitian ini berupa angket atau kuesioner untuk memperoleh informasi tentang Pengaruh Kompensasi, Kepuasan Kerja, Motivasi Kerja dan Gaya
Kepemimpinan terhadap Kinerja Karyawan pada UMKM di desa Wisata Bobung Gunungkidul Yogyakarya. Metode yang digunakan dalam penelitian ini yaitu dengan cara menyebarkan kuesioner atau daftar pertanyaan kepada karyawan pada UMKM di desa Wisata Bobung Gunungkidul Yogyakarta.

\section{Teknik Analisis Data}

\section{1) Analisis Deskriptif}

Analisis deskriptif digunakan untuk menganalisa data satu persatu yang didasarkan pada jawaban responden yang dihuimpun berdasarkan kuesioner yang telah diisi responden selama penelitian berlangsung. Data yang diperoleh dari lapangan disajikan dalam bentuk deskripsi dari masing-masing variabel bebas maupun variabel terikat. Adapun berdasarkan kriteria yang dipakai pada kategori jawaban responden, maka untuk lebih memudahkan digunakan 3 kategori yaitu tinggi, sedang, dan rendah.

\section{2) Uji Prasyarat Analisis}

Uji persyaratan analisis dimaksudkan untuk mengatahui apakah data yang dikumpulkan memenuhi syarat untuk dianalisis dengan teknik statistik yang dipilih. Ada empat tahap pengujian yang harus dipenuhi sebelum tahap pengujian hipotesis, yaitu:

\section{a) Uji Normalitas}

Uji normalitas merupakan pengujian apakah dalam sebuah regresi, variabel 


\section{JURNAL NOMINAL / VOLUME V NOMOR 2 / TAHUN 2016}

dependen, independen atau keduanya memiliki distribusi normal atau tidak (Imam Ghozali, 2011: 160). Teknik uji normalitas yang digunakan pada penelitian ini adalah Kolmogorov-smirnov.

\section{b) Uji Linearitas}

Uji linearitas bertujuan untuk mengetahui hubungan linear antara dua variabel. Linearitas dapat diartikan sebagai hubungan yang linear antar variabel, yaitu apabila terjadi perubahan pada satu variabel maka variabel lain pun akan mengalami perubahan dengan besaran yang sejajar. Pengujian linearitas berfungsi atau bertujuan untuk mengatahui apakah penelitian linear (lurus) atau tidak linear (tidak lurus).

\section{c) Uji Multikolinearitas}

Uji Multikolinearitas merupakan bentuk pengujian untuk asumsi dalam analisis regresi berganda. Multikolinearitas terjadi apabila terdapat hubungan yang kuat antara variabel independen dalam model regresi. Apabila terjadi gejala multikolinearitas, salah satu langkah untuk memperbaiki model adalah dengan menghilangkan variabel dari model regresi, sehingga bisa dipilih model yang paling baik (Purbayu Budi Santosa dan Ashari 2005).

\section{d) Uji Heteroskedastisitas}

Heteroskedastisitas adalah suatu kondisi apabila variabel pengganggu mempunyai varian yang berbeda dari satu amatan ke amatan yang lain atau varian antara variabel dalam model tidak konstan.
Asumsi varian dikatakan konstan apabila distribusi residual tidak dipengaruhi oleh besar kecilnya variabel independen.

\section{2) Uji Hipotesis}

\section{a) Analisis Regresi Linear Sederhana}

Analisis regresi sederhana didasarkan pada hubungan fungsional ataupun kausal satu variabel independen dengan satu variabel dependen (Sugiyono, 2014: 261). Analisis ini dilakukan untuk membuktikan hipotesis yang diajukan, apakah masingmasing variabel independen (Kompensasi, Kepuasan Kerja, Motivasi Kerja dan Gaya Kepemimpinan) berpengaruh terhadap Kinerja Karyawan pada UMKM di desa Wisata Bobung Gunungkidul Yogyakarta.

(1) Persamaan regresi linear sederhana

(2) Mencari koefisien determinasi $\left(\mathrm{r}^{2}\right)$

(3) Menguji signifikansi koefisien korelasi dengan uji $\mathrm{t}$

\section{b) Analisis Regresi Linear Berganda}

Analisis regresi berganda digunakan oleh peneliti untuk meramalkan bagaimana keadaan variabel dependen (kriterium) apabila dua atau lebih variabel independen sebagai faktor prediktor dimanipulasi (Sugiyono, 2014: 275).

(1) Membuat persamaan garis regresi empat prediktor

(2) Mencari koefisien determinasi $\left(\mathrm{R}^{2}\right)$

(3) Menguji signifikansi dengan Uji F. 


\section{JURNAL NOMINAL / VOLUME V NOMOR 2 / TAHUN 2016}

\section{HASIL PENELITIAN \\ DAN \\ PEMBAHASAN}

\section{Uji Validitas dan Reliabilitas}

Berdasarkan pengujian instrumen yang telah dilakukan, maka dapat dilihat bahwa item instrumen pada variabel kompensasi total pertanyaan 6 dan valid. Item instrumen pada variabel kepuasan kerja total pertanyaan 21 tetapi yang tidak valid 3. Item instrumen pada variabel motivasi kerja total pertanyaan 20 tetapi yang tidak valid 2. Item instrumen pada variabel gaya kepemimpinan total pertanyaan 21 tetapi yang tidak valid 2. Item instrumen pada variabel kinerja karyawan total pertanyaan 12 tetapi yang tidak valid 1 . Dari hasil Uji validitas yang dilakukan, Butir pernyataan dinilai tidak valid jika memiliki nilai pearson correlation $<0,3061$.

Hasil Uji Reliabilitas menunjukkan bahwa variabel Kompensasi, Kepuasan Kerja, Motivasi Kerja dan Gaya Kepemimpinan terhadap Kinerja Karyawan masing-masing mempunyai tingkat reliabilitas sesuai standar yang telah ditentukan yaitu Cronbach's Alpha Based on Standardized items $\geq 0,600$. Dengan demikian instrumen-instrumen tersebut telah memenuhi syarat sebagai alat mengambil data penelitian karena telah teruji tingkat validitas dan reliabilitasnya.

\section{Hasil Uji Prasyarat Analisis}

\section{a. Uji Normalitas}

Hasil uji normalitas untuk variabel penelitian disajikan sebagai berikut:

Tabel 7. Hasil Uji Normalitas

\begin{tabular}{lcc}
\multicolumn{1}{c}{ Variabel } & Sig & Keterangan \\
\hline Kompensasi & 0,071 & Normal \\
\hline $\begin{array}{l}\text { Kepuasan } \\
\text { Kerja }\end{array}$ & 0,217 & Normal \\
\hline Motivasi Kerja & 0,123 & Normal \\
\hline $\begin{array}{l}\text { Gaya } \\
\text { Kepemimpinan }\end{array}$ & 0,073 & Normal \\
\hline $\begin{array}{l}\text { Kinerja } \\
\text { Karyawan }\end{array}$ & 0,093 & Normal \\
\hline
\end{tabular}

Sumber: Data Primer yang diolah Tahun 2016.

Hasil uji normalitas pada tabel 7 di atas dapat diketahui bahwa semua variabel penelitian mempunyai nilai signifikansi lebih besar dari 0,05 (sig>0,05), sehingga dapat disimpulkan bahwa data penelitian berdistribusi normal.

\section{a. Uji Linearitas}

Hasil rangkuman uji linearitas disajikan sebagai berikut:

Tabel 8. Hasil Uji Linearitas

\begin{tabular}{lcc}
\hline \multicolumn{1}{c}{ Variabel } & Sig & Keterangan \\
\hline Kompensasi & 0,069 & Linear \\
\hline Kepuasan Kerja & 0,069 & Linear \\
\hline Motivasi Kerja & 0,333 & Linear \\
\hline Gaya Kepemimpinan & 0,108 & Linear \\
\hline $\begin{array}{c}\text { Sumber: Data Primer yang diolah } \\
\text { 2016. }\end{array}$ & &
\end{tabular}

Hasil uji linearitas pada tabel 8 di atas dapat diketahui bahwa semua variabel penelitian mempunyai nilai signifikansi lebih besar dari $0,05 \quad($ sig $>0,05)$, hal ini menunjukkan bahwa semua variabel penelitian adalah linear. 


\section{JURNAL NOMINAL / VOLUME V NOMOR 2 / TAHUN 2016}

\section{b. Uji Multikolinearitas}

Hasil uji multikolinearitas dapat dilihat pada tabel 9 sebagai berikut:

Tabel 9. Hasil Uji Multikolinearitas

\begin{tabular}{lccc}
\hline \multicolumn{1}{c}{ Variabel } & Tolerance & VIF & Keterangan \\
\hline Kompensasi & 0,747 & 1,339 & $\begin{array}{c}\text { Tidak ada } \\
\text { korelasi }\end{array}$ \\
\hline Kepuasan Kerja & 0,785 & 1,274 & $\begin{array}{c}\text { Tidak ada } \\
\text { korelasi }\end{array}$ \\
\hline Motivasi Kerja & 0,889 & 1,124 & $\begin{array}{c}\text { Tidak ada } \\
\text { korelasi }\end{array}$ \\
\hline $\begin{array}{l}\text { Gaya } \\
\text { Kepemimpinan }\end{array}$ & 0,828 & 1,208 & $\begin{array}{c}\text { Tidak ada } \\
\text { korelasi }\end{array}$ \\
\hline
\end{tabular}

Sumber: Data Primer yang diolah Tahun 2016.

Dari hasil uji multikolinearitas dengan menganalisis matrik korelasi antar variabel independen diperoeh tolerance $\geq 0,10$ atau sama dengan nilai VIF $\leq 10$ sehingga disimpulkan variabel independen tidak ada korelasi.

\section{c. Uji Heteroskedastisitas}

Berikut ini adalah hasil uji heteroskedastisitas terhadap model regresi pada penelitian ini:

Tabel 10. Hasil Uji Heteroskedastisitas

\begin{tabular}{|c|c|c|}
\hline Variabel & Sig. & Keterangan \\
\hline Kompensasi & 0,896 & $\begin{array}{c}\text { Tidak terjadi } \\
\text { heteroskedastisitas }\end{array}$ \\
\hline $\begin{array}{l}\text { Kepuasan } \\
\text { Kerja }\end{array}$ & 0,858 & $\begin{array}{c}\text { Tidak terjadi } \\
\text { heteroskedastisitas }\end{array}$ \\
\hline Motivasi Kerja & 0,113 & $\begin{array}{c}\text { Tidak terjadi } \\
\text { heteroskedastisitas }\end{array}$ \\
\hline $\begin{array}{l}\text { Gaya } \\
\text { Kepemimpinan }\end{array}$ & 0,167 & $\begin{array}{c}\text { Tidak terjadi } \\
\text { heteroskedastisitas }\end{array}$ \\
\hline
\end{tabular}

Sumber: Data Primer yang diolah Tahun 2016.

Tabel 10 di atas menunjukkan bahwa semua variabel mempunyai nilai signifikansi lebih besar dari 0,05 sehingga dapat disimpulkan bahwa model regresi pada penelitian ini tidak terjadi heteroskedastisitas.

\section{Uji Hipotesis}

Pengujian hipotesis dalam penelitian bertujuan untuk membuktikan pengaruh kompensasi, kepuasan kerja, motivasi kerja, dan gaya kepemimpinan terhadap kinerja karyawan pada UMKM di desa Wisata Bobung Gunungkidul Yogyakarta. Adapun hasil pengujian hipotesis disajikan sebagai berikut:

1) Pengujian Hipotesis Pertama

\begin{tabular}{|c|c|c|c|c|c|}
\hline $\begin{array}{l}\text { Model } \\
\text { Regresi } \\
\text { X1 }\end{array}$ & $\mathbf{r}^{2}$ & $\begin{array}{c}\mathrm{t} \\
\mathrm{hitun} \\
\mathrm{g}\end{array}$ & Sig. & $\begin{array}{l}\text { Koefisi } \\
\text { en } \\
\text { Regresi }\end{array}$ & $\begin{array}{c}\text { Consta } \\
n t\end{array}$ \\
\hline $\begin{array}{c}\text { X1- } \\
\text { Y }\end{array}$ & 0,290 & 6,919 & 0,000 & 0,628 & 23,436 \\
\hline
\end{tabular}

Tabel 11. Rangkuman Hasil Analisis

Regresi Sederhana (X1-Y)

Sumber: Data Primer yang diolah Tahun 2016.

Berdasarkan tabel 11 dapat disimpulkan bahwa terdapat pengaruh positif dan signifikan Kompensasi terhadap Kinerja Karyawan pada UMKM di desa Wisata Bobung Gunungkidul Yogyakarta. Kesimpulan ini menunjukkan bahwa hipotesis 1 yaitu "Kompensasi mempunyai pengaruh positif terhadap kinerja karyawan pada UMKM di desa Wisata Bobung Gunungkidul Yogyakarta” diterima.

Berdasarkan hasil penelitian ini diketahui adanya pengaruh kompensasi terhadap kinerja karyawan. Pengaruh yang ditimbulkan bersifat positif, artinya bahwa semakin tinggi tingkat kepuasan karyawan terhadap kompensasi yang diberikan 


\section{JURNAL NOMINAL / VOLUME V NOMOR 2 / TAHUN 2016}

perusahaan maka semakin tinggi kinerja karyawan tersebut. Hasil penelitian ini mendukung penelitian terdahulu yang dilakukan oleh Utami Tunjung Sari (2014), Rafi Jody Kurnia (2016), dan Hanifani Nur Aziz (2015). Utami Tunjung Sari (2014) meneliti tentang "Pengaruh Kompensasi dan Gaya Kepemimpinan terhadap Kinerja Karyawan Melalui Motivasi Kerja Karyawan CV. Terus Jaya Cilacap“. Hasil penelitian Utami Tunjung Sari (2014) menunjukkan bahwa kompensasi berpengaruh positif terhadap kinerja karyawan. Rafi Jody Kurnia (2016) meneliti tentang "Pengaruh Kompensasi dan Motivasi Kerja terhadap Kinerja Karyawan Rumah Sakit Condong Catur Yogyakarta“. Hasil penelitian Rafi Jody Kurnia (2016) menunjukkan bahwa kompensasi berpengaruh positif terhadap kinerja karyawan. Hanifani Nur Aziz (2015) meneliti tentang "Pengaruh Kompensasi terhadap Kinerja Karyawan di PT.Catur Tunggal Munggaran“. Hasil penelitian Hanifani Nur Aziz (2015) menunjukkan bahwa kompensasi berpengaruh positif terhadap kinerja karyawan.

Menurut Hasibuan (2007: 67) kinerja karyawan adalah suatu hasil kerja yang dapat dicapai seseorang dalam melaksanakan tugas-tugas yang dibebankan kepadanya yang didasarkan atas kecakapan, pengalaman, kesungguhan, serta waktu. Perusahaan pasti menginginkan para karyawannya memilii kinerja yang baik agar proses pencapaian tujuan berjalan lancar. Dalam mewujudkan kinerja karyawan yang diinginkan, banyak faktor yang mungkin mempengaruhi bagi karyawan, salah satunya adalah kompensasi.

\section{2) Pengujian Hipotesis Kedua}

Tabel 12. Rangkuman Hasil Analisis Regresi Sederhana (X2-Y).

\begin{tabular}{cccccc}
\hline $\begin{array}{c}\text { Model } \\
\text { Regres } \\
\text { i X2 }\end{array}$ & $\mathbf{r}^{2}$ & t hitung & Sig. & $\begin{array}{c}\text { Koefisie } \\
\mathbf{n} \\
\text { Regresi }\end{array}$ & Constant \\
\hline X2-Y & 0,30 & 7,08 & 0,00 & 0,271 & 19,491 \\
& 0 & 2 & 0 & & \\
\hline
\end{tabular}

Sumber: Data Primer yang diolah Tahun 2016.

Berdasarkan tabel 12 dapat disimpulkan bahwa terdapat pengaruh positif dan signifikan Kepuasan Kerja terhadap Kinerja Karyawan pada UMKM di desa Wisata Bobung Gunungkidul Yogyakarta. Kesimpulan ini menunjukkan bahwa hipotesis 2 yaitu "Kepuasan Kerja mempunyai pengaruh positif terhadap kinerja karyawan pada UMKM di desa Wisata Bobung Gunungkidul Yogyakarta” diterima.

Berdasarkan hasil penelitian ini diketahui adanya pengaruh kepuasan kerja terhadap kinerja karyawan. Pengaruh yang ditimbulkan bersifat positif, artinya bahwa semakin tinggi tingkat kepuasan kerja karyawan pada perusahaan maka semakin tinggi kinerja karyawan tersebut. Hasil 


\section{JURNAL NOMINAL / VOLUME V NOMOR 2 / TAHUN 2016}

penelitian ini mendukung penelitian terdahulu yang dilakukan oleh Akhsin Rustam Aji (2015), Umarudin Azis (2015), dan Febri Furqon Artadi(2015). Akhsin Rustam Aji (2015) meneliti tentang "Pengaruh Motivasi Kerja dan Kepuasan Kerja terhadap Kinerja Pegawai Sekretariat daerah Kabupaten Wonosobo “. Hasil penelitian Akhsin Rustam Aji (2015) menunjukkan bahwa kepuasan kerja berpengaruh positif terhadap kinerja karyawan. Umarudin Azis (2015) meneliti tentang "Pengaruh Budaya Organisasi dan Kepuasan Kerja terhadap Kinerja Karyawan RRI Yogyakarta“. Hasil penelitian Umarudin Azis (2015) menunjukkan bahwa kepuasan kerja berpengaruh positif terhadap kinerja karyawan. Febri Furqon Artadi (2015) meneliti tentang "Pengaruh Kepuasan Kerja dan Beban Kerja terhadap Kinerja Karyawan pada PT. Merapi Agung Lestari“. Hasil penelitian Febri Furqon Artadi (2015) menunjukkan bahwa kepuasan kerja berpengaruh positif terhadap kinerja karyawan.

Menurut Hasibuan (2009: 202) kepuasan kerja adalah sikap emosional yang menyenangkan dan mencintai pekerjaannya. Sikap ini dicerminkan oleh moral kerja, kedisiplinan dan prestasi kerja. Kepuasan kerja dinikmati dalam pekerjaan, luar pekerjaan dan kombinasi dalam dan luar pekerjaan. Dengan demikian kepuasan kerja merupakan perasaaan yang dirasakan oleh bawahan atau karyawan terhadap pekerjaannya, lingkungan pekerjaannya serta imbalan yang diterima terhadap hasil pekerjaannya. Perasaan tersebut dapat berupa perasaan senang, tidak senang, nyaman ataupun tidak nyaman.

3) Pengujian Hipotesis Ketiga

Tabel 13. Rangkuman Hasil Analisis Regresi Sederhana (X3-Y)

\begin{tabular}{cccccc}
\hline $\begin{array}{c}\text { Model } \\
\text { Regresi } \\
\text { X3 }\end{array}$ & $\mathbf{r}^{2}$ & t hitung & Sig. & $\begin{array}{c}\text { Koefisien } \\
\text { Regresi }\end{array}$ & $\begin{array}{c}\text { Consta } \\
n t\end{array}$ \\
\hline X3-Y & 0,161 & 4,747 & 0,00 & 0,216 & 22,651 \\
& & & 0 & & \\
\hline
\end{tabular}

Sumber: Data Primer yang diolah Tahun 2016.

Berdasarkan tabel 12 dapat disimpulkan bahwa terdapat pengaruh positif dan signifikan Motivasi Kerja terhadap Kinerja Karyawan pada UMKM di desa Wisata Bobung Gunungkidul Yogyakarta. Kesimpulan ini menunjukkan bahwa hipotesis 3 yaitu "Motivasi Kerja mempunyai pengaruh positif terhadap kinerja karyawan pada UMKM di desa Wisata Bobung Gunungkidul Yogyakarta" diterima.

Berdasarkan hasil penelitian ini diketahui adanya pengaruh motivasi kerja terhadap kinerja karyawan. Pengaruh yang ditimbulkan bersifat positif, artinya bahwa semakin tinggi motivasi kerja karyawan maka semakin tinggi kinerja karyawan tersebut. Hasil penelitian ini mendukung penelitian terdahulu yang dilakukan oleh Dany Marthen (2016), Anna Rizka Nurani 
(2016), dan Febrian Army Wijaya (2015).

Dany Marthen (2016) meneliti tentang "Pengaruh Gaya Kepemimpinan Transformasional dan Motivasi Kerja terhadap Kinerja Karyawan (Studi pada CV. Batik Indah Rara Djonggrang)“. Hasil penelitian Dany Marthen (2016) menunjukkan bahwa motivasi kerja berpengaruh positif terhadap kinerja karyawan. Anna Rizka Nurani (2016) meneliti tentang "Pengaruh Budaya Organisasi dan Motivasi Kerja terhadap Kinerja Pegawai Balai Diklat Industri Regional IV Yogyakarta“. Hasil penelitian Anna Rizka Nurani (2016) menunjukkan bahwa motivasi kerja berpengaruh positif terhadap kinerja karyawan. Febrian Army Wijaya (2015) meneliti tentang "Pengaruh Motivasi Kerja terhadap Kinerja Karyawan pada Kantor Dinas Pertanian Kabupaten Klaten“. Hasil penelitian Febrian Army Wijaya (2015) menunjukkan bahwa motivasi kerja berpengaruh positif terhadap kinerja karyawan.

Motivasi (motivasion) dalam manajemen hanya ditujukan pada sumber daya manusia umumnya dan bawahan khususnya. Pentingnya motivasi karena motivasi adalah hal yang menyebabkan, menyalurkan, dan mendukung prilaku manusia, supaya mau bekerja giat dan antusias mencapai hasil yang optimal.
4) Pengujian Hipotesis Keempat

Tabel 14. Rangkuman Hasil Analisis Regresi Sederhana (X4-Y)

\begin{tabular}{llllll}
\hline $\begin{array}{c}\text { Model } \\
\text { Regresi X4 }\end{array}$ & $\mathbf{r}^{2}$ & $\begin{array}{c}\mathbf{t} \\
\text { hitung }\end{array}$ & Sig. & $\begin{array}{l}\text { Koefisien } \\
\text { Regresi }\end{array}$ & $\begin{array}{c}\text { Const } \\
\text { ant }\end{array}$ \\
\hline X4-Y & 0,293 & 6,962 & 0,000 & 0,242 & 20,610 \\
\hline
\end{tabular}

Sumber: Data Primer yang diolah Tahun 2016.

Berdasarkan tabel 14 dapat disimpulkan bahwa terdapat pengaruh positif dan signifikan Gaya Kepemimpinan terhadap Kinerja Karyawan pada UMKM di desa Wisata Bobung Gunungkidul Yogyakarta. Kesimpulan ini menunjukkan bahwa hipotesis 4 yaitu "Gaya Kepemimpinan mempunyai pengaruh positif terhadap kinerja karyawan pada UMKM di desa Wisata Bobung Gunungkidul Yogyakarta” diterima.

Berdasarkan hasil penelitian ini diketahui adanya pengaruh gaya kepemimpinan terhadap kinerja karyawan. Pengaruh yang ditimbulkan bersifat positif, artinya bahwa semakin tinggi tingkat kepuasan karyawan terhadap gaya kepemimpinan yang diterapkan oleh atasan maka semakin tinggi kinerja karyawan tersebut. Hasil penelitian ini mendukung penelitian terdahulu yang dilakukan oleh Danang Setya Ramadhani (2016), Cahyo Adi Nugroho (2015), dan Galih Aryo Nimpuno (2015). Danang Setya Ramadhani (2016) meneliti tentang "Pengaruh Kepemimpinan dan Motivasi terhadap Kinerja Pegawai di Balai Pengembangan 


\section{JURNAL NOMINAL / VOLUME V NOMOR 2 / TAHUN 2016}

Kegiatan Belajar (BPKB) Daerah Istimewa Yogyakarta (DIY)“. Hasil penelitian Danang Setya Ramadhani (2016) menunjukkan bahwa gaya kepemimpinan berpengaruh positif terhadap kinerja karyawan. Cahyo Adi Nugroho (2015) meneliti tentang "Pengaruh Gaya Kepemimpinan dan Disiplin Kerja terhadap Kinerja Pegawai Dinas Pariwisata Daerah Istimewa Yogyakarta“. Hasil penelitian Cahyo Adi Nugroho (2015) menunjukkan bahwa gaya kepemimpinan berpengaruh positif terhadap kinerja karyawan. Galih Aryo Nimpuno (2015) meneliti tentang "Pengaruh Disiplin Kerja dan Gaya Kepemimpinan terhadap Kinerja Karyawan UD. Pustaka Pelajar Yogyakarta“. Hasil penelitian Galih Aryo Nimpuno (2015) menunjukkan bahwa gaya kepemimpinan berpengaruh positif terhadap kinerja karyawan.

Kinerja pada dasarnya adalah apa yang dilakukan atau tidak dilakukan karyawan sehingga mempengaruhi seberapa banyak mereka memberi kontribusi kepada organisasi atau perusahaan. Kinerja pegawai yang tidak baik secara langsung akan mempengaruhi kinerja organisasi sehingga mengganggu stabilitas perusahaan. Apabila masalah tersebut tidak diatasi dengan baik akan menyebabkan terganggunya pencapaian tujuan organisasi. Oleh karena itu, diperlukan berbagai pendekatan dalam mengatasi masalah tersebut. Gaya kepemimpinan merupakan salah satu faktor yang berpengaruh terhadap kinerja karyawan.

5) Pengujian Hipotesis Kelima

Tabel 15. Rangkuman Hasil Analisis Regresi Berganda (X-Y)

\begin{tabular}{|c|c|c|c|c|c|}
\hline Variabel & $\begin{array}{l}\text { Koefisi } \\
\text { en Beta }\end{array}$ & Sig F & $\mathbf{R}^{2}$ & $\begin{array}{c}\text { F } \\
\text { hitung }\end{array}$ & $\begin{array}{c}\text { F } \\
\text { Tabel }\end{array}$ \\
\hline Constant & 6,607 & 0,006 & 0,572 & 38,054 & 2,45 \\
\hline Kompensasi & 0,298 & & & & \\
\hline Kepuasan & 0,158 & & & & \\
\hline \multicolumn{6}{|l|}{ Kerja } \\
\hline Motivasi & 0,106 & & & & \\
\hline \multicolumn{6}{|l|}{ Kerja } \\
\hline Gaya & 0,149 & & & & \\
\hline $\begin{array}{l}\text { Kepemimpin } \\
\text { an }\end{array}$ & & & & & \\
\hline
\end{tabular}

Sumber: Data Primer yang diolah Tahun 2016

Berdasarkan tabel 15 dapat disimpulkan bahwa terdapat pengaruh positif dan signifikan Kompensasi, Kepuasan Kerja, Motivasi Kerja, dan Gaya Kepemimpinan terhadap Kinerja Karyawan pada UMKM di desa Wisata Bobung Gunungkidul Yogyakarta. Kesimpulan ini menunjukkan bahwa hipotesis 5 yaitu "Kompensasi, Kepuasan Kerja, Motivasi Kerja, dan Gaya Kepemimpinan mempunyai pengaruh positif terhadap Kinerja Karyawan pada UMKM di desa Wisata Bobung Gunungkidul Yogyakarta" diterima.

Berdasarkan hasil penelitian ini diketahui adanya pengaruh positif dari Kompensasi, Kepuasan Kerja, Motivasi Kerja, dan Gaya Kepemimpinan secara 


\section{JURNAL NOMINAL / VOLUME V NOMOR 2 / TAHUN 2016}

bersama-sama terhadap Kinerja Karyawan pada UMKM di desa Wisata Bobung Gunungkidul Yogyakarta. Hasil penelitian ini mendukung penelitian terdahulu yang dilakukan oleh Udit Bagaskoro (2015), Suminto (2013), Ari Kurniadini (2013), dan Renggani Nur'aini Vidianingtyas dan Wika Harisa Putri (2014). Udit Bagaskoro (2015) meneliti tentang "Pengaruh Gaya Kepemimpinan, Motivasi Kerja dan Komitmen Organisasi terhadap Kinerja Pegawai Pengelola Keuangan di Universitas Negeri Yogyakarta“. Hasil penelitian Udit Bagaskoro (2015) menunjukkan bahwa gaya kepemimpinan dan motivasi berpengaruh positif terhadap kinerja karyawan. Suminto (2013) meneliti tentang "Pengaruh Motivasi Kerja, Komitmen Organisasi dan Kompensasi terhadap Kinerja Karyawan PT. Nissan Radin Inten Jakarta Timur“. Hasil penelitian Suminto (2013) menunjukkan bahwa gaya motivasi kerja dan kompensasi berpengaruh positif terhadap kinerja karyawan. Ari Kurniadini (2013) meneliti tentang "Pengaruh Kepuasan Kerja dan Komitmen Karyawan terhadap Kinerja Karyawan PT. Vidya Rejeki Tama Cabang Yogyakarta“. Hasil penelitian Ari Kurniadini (2013) menunjukkan bahwa kepuasan kerja berpengaruh positif terhadap kinerja karyawan. Renggani Nur'aini Vidianingtyas dan Wika Harisa Putri (2014) meneliti tentang "Pengaruh Kompensasi, Kepuasan Kerja, Motivasi Kerja dan Gaya
Kepemimpinan terhadap Kinerja Karyawan pada perusahaan Jasa Katering di Daerah Istimewa Yogyakarta“. Hasil penelitian Renggani Nur'aini Vidianingtyas dan Wika Harisa Putri (2014) menunjukkan bahwa Kompensasi, Kepuasan Kerja, Motivasi Kerja dan Gaya Kepemimpinan berpengaruh positif terhadap kinerja karyawan.

\section{SIMPULAN DAN SARAN}

\section{Simpulan}

Berdasarkan hasil analisis dan Berdasarkan hasil penelitian dan pembahasan, maka dapat ditarik beberapa kesimpulan sebagai berikut.

1. Kompensasi mempunyai pengaruh positif terhadap kinerja karyawan pada UMKM di desa Wisata Bobung Gunungkidul Yogyakarta. Hal ini dibuktikan dari nilai thitung $(6,919)$ lebih besar daripada $t_{\text {tabel }}$ $(1,658)$ dan nilai signifikansinya lebih kecil dari 0,05 yaitu 0,000 .

2. Kepuasan kerja mempunyai pengaruh positif terhadap kinerja karyawan pada UMKM di desa Wisata Bobung Gunungkidul Yogyakarta. Hal ini dibuktikan dari nilai thitung $(7,082)$ lebih besar daripada $t_{\text {tabel }}(1,658)$ dan nilai signifikansinya lebih kecil dari 0,05 yaitu 0,000 .

3. Motivasi kerja mempunyai pengaruh positif terhadap kinerja karyawan pada UMKM di desa Wisata Bobung Gunungkidul Yogyakarta. Hal ini 


\section{JURNAL NOMINAL / VOLUME V NOMOR 2 / TAHUN 2016}

dibuktikan dari nilai $t_{\text {hitung }}(4,747)$ lebih besar daripada tabel $(1,658)$ dan nilai signifikansinya lebih kecil dari 0,05 yaitu 0,000 .

4. Gunungkidul Yogyakarta. Hal ini dibuktikan dari nilai thitung $(4,747)$ lebih besar daripada $t_{\text {tabel }}(1,658)$ dan nilai signifikansinya lebih kecil dari 0,05 yaitu 0,000 .

5. Gunungkidul Yogyakarta. Hal ini dibuktikan dari nilai $t_{\text {hitung }}(4,747)$ lebih besar daripada $t_{\text {tabel }}(1,658)$ dan nilai signifikansinya lebih kecil dari 0,05 yaitu 0,000 .

6. Gaya kepemimpinan mempunyai pengaruh positif terhadap kinerja karyawan pada UMKM di desa Wisata Bobung Gunungkidul Yogyakarta. Hal ini dibuktikan dari nilai $t_{\text {hitung }}(6,962)$ lebih besar daripada tabel $(1,658)$ dan nilai signifikansinya lebih kecil dari 0,05 yaitu 0,000 .

Kompensasi, Kepuasan Kerja, Motivasi Kerja dan Gaya kepemimpinan mempunyai pengaruh positif terhadap kinerja karyawan pada UMKM di desa Wisata Bobung Gunungkidul Yogyakarta. Hal ini dibuktikan dari nilai $F_{\text {hitung }}(38,054)$ lebih besar daripada $F_{\text {tabel }}(2,45)$, dan nilai signifikansinya lebih kecil dari 0,05 yaitu 0,006 .

\section{Saran}

Berdasarkan hasil penelitian, pembahasan dan kesimpulan yang diperoleh, maka saran yang dapat diberikan sebagai berikut.

1. Bagi Pimpinan UMKM di desa Wisata Bobung Gunungkidul Yogyakarta

a. Dilihat dari data kuesioner masih terdapat karyawan yang mendapatkan kompensasi belum sesuai dengan standar yang berlaku dan tunjangan yang diberikan juga belum memenuhi harapan sebaiknya perusahaan harus lebih memperhatikan kesejahteraan karyawan sebagai aset perusahaan dengan cara memberikan kompensasi dan tunjangan yang sesuai.

b. Sebaiknya atasan memberi motivasi yang lebih kepada karyawan agar dapat meningkatkan kinerja karyawan tersebut karena berdasarkan data yang didapat masih terdapat karyawan yang tidak merasa senang akan pekerjaannya.

c. Berdasarkan data yang diperoleh atasan masih kurang memperhitungkan apa yang dibutuhkan karyawan dan beberapa karyawan masih mengeluhkan kurangnya bantuan dari atasan untuk mencapai tujuan organisasi. Sebaiknya, atasan lebih memperhatikan bawahan dengan begitu akan terjalim kedekatan antara bawahan agar pemimpin dapat 


\section{JURNAL NOMINAL / VOLUME V NOMOR 2 / TAHUN 2016}

mengontrol dan mengarahkan
karyawan untuk berfikir
inovatif dan kreatif
meningkatkan kinerjanya.

d. Peneliti Selanjutnya

Peneliti selanjutnya dapat mengembangkan penelitian ini dengan meneliti faktor lain yang dapat memengaruhi kinerja karyawan, misalnya faktor komitmen organisasi, budaya organisasi, dan lingkungan kerja. Peneliti selanjutnya juga dapat menggunakan metode lain dalam meneliti kinerja karyawan, misalnya melalui wawancara mendalam terhadap karyawan. Selain itu, peneliti selanjutnya akan lebih baik jika mengembangkan penelitian serta menambah kekurangan yang ada pada

\section{DAFTAR PUSTAKA}

Abdul Halim dkk. (2003). Sistem Pengendalian Manajemen. Yogyakarta: AMP YKPN.

Akhsin Rustam Aji. (2015). "Pengaruh Motivasi Kerja dan Kepuasan Kerja terhadap Kinerja Pegawai Sekretariat daerah Kabupaten Wonosobo". Skripsi. Fakultas Ilmu Sosial. Universitas Negeri Yogyakarta.

Anna Rizka Nurani. (2016). "Pengaruh Budaya Organisasi dan Motivasi Kerja terhadap Kinerja Pegawai Balai Diklat Industri Regional IV Yogyakarta”. Skripsi. Fakultas Ilmu Sosial. Universitas Negeri Yogyakarta.

Ari Kurniadini. (2016). "Pengaruh Kepuasan Kerja dan Komitmen Karyawan terhadap Kinerja Karyawan PT. Vidya Rejeki
Tama Cabang Yogyakarta". Skripsi. Fakultas Ekonomi. Universitas Negeri Yogyakarta.

Cahyo Adi Nugroho. (2015). "Pengaruh Gaya Kepemimpinan dan Disiplin Kerja terhadap Kinerja Pegawai Dinas Pariwisata Daerah Istimewa Yogyakarta”. Skripsi. Fakultas Ekonomi. Universitas Negeri Yogyakarta.

Dany Marthen. (2016). "Pengaruh Gaya Kepemimpinan Transformasional dan Motivasi Kerja terhadap Kinerja Karyawan (Studi pada CV. Batik Indah Rara Djonggrang)". Skripsi. Fakultas Ekonomi. Universitas Negeri Yogyakarta.

Danang Setya Ramadhani. (2016). "Pengaruh Kepemimpinan dan Motivasi terhadap Kinerja Pegawai di Balai Pengembangan Kegiatan Belajar (BPKB) Daerah Istimewa Yogyakarta (DIY)". Skripsi. Fakultas Ekonomi. Universitas Negeri Yogyakarta.

Febri Furqon Artadi. (2015). "Pengaruh Kepuasan Kerja dan Beban Kerja terhadap Kinerja Karyawan pada PT. Merapi Agung Lestari”. Skripsi. Fakultas Ekonomi. Universitas Negeri Yogyakarta.

Febrian Army Wijaya. (2015). "Pengaruh Motivasi Kerja terhadap Kinerja Karyawan pada Kantor Dinas Pertanian Kabupaten Klaten". Skripsi. Fakultas Ekonomi. Universitas Negeri Yogyakarta.

Galih Aryo Nimpuno. (2015). "Pengaruh Disiplin Kerja dan Gaya Kepemimpinan terhadap Kinerja Karyawan UD. Pustaka Pelajar Yogyakarta". Skripsi. Fakultas Ekonomi. Universitas Negeri Yogyakarta.

Hani Handoko. (2010). Manajemen Personalia \& Sumberdaya Manusia. Edisi kedua. Yogyakarta: BPFE Yogyakarta.

Hanifani Nur Aziz. (2015). "Pengaruh Kompensasi terhadap Kinerja Karyawan 
di PT.Catur Tunggal Munggaran”. Tugas Akhir. Fakultas Ekonomi. Universitas Negeri Yogyakarta.

Hasibuan, Malayu S.P. (2005). Manajemen Sumber Daya Manusia, Edisi Revisi. Jakarta: PT Bumi Aksara.

(2007). Manajemen

Sumber Daya Manusia. Cetakan kesembilan. Jakarta: PT Bumi Aksara.

(2008). Manajemen

Sumber Daya Manusia, Edisi Revisi. Jakarta: PT Bumi Aksara.

Heidjrachman dan Suad Husnan. (1990). Manajemen Personalia. Edisi keempat. Yogyakarta. BPFE.

Imam Ghozali. (2011). Aplikasi Analisis Multivarat Dengan Program IBM SPSS 19. Edisi kelima.Semarang: Badan Penerbit Universitas Diponegoro.

Kuncoro, Mudrajad. (2003). Metode Riset Untuk Bisnis dan Ekonomi. Jakarta: Erlangga.

Rafi Jody Kurnia. (2016). "Pengaruh Kompensasi dan Motivasi Kerja terhadap Kinerja Karyawan Rumah Sakit Condong Catur Yogyakarta". Skripsi. Fakultas Ekonomi. Universitas Negeri Yogyakarta.

Renggani Nur'aini Vidianingtyas dan Wika Harisa Putri. (2014). Pengaruh Kompensasi, Kepuasan Kerja, Motivasi Kerja, dan Gaya Kepemimpinan terhadap Kinerja Karyawan pada Perusahaan Katering di Daerah Istimewa Yogyakarta. Jurnal Bisnis dan Ekonomi. Vol. 5, No. 1, Juni 2014. 99-110. Universitas Janabadra.

Sudarwan Danim. (2004). Motivasi Kepemimpinan dan Efejktivitas Kelompok. Jakarta: Rineka Cipta.
Sugiyono. (2014). Statistika untuk Penelitian. Cetakan ke-25. Bandung: Alfabeta.

Suharsimi Arikunto. (2007). Manajemen Penelitian. Jakarta: Penerbit Rineka Cipta.

Suminto. (2013). "Pengaruh Motivasi Kerja, Komitmen Organisasi dan Kompensasi terhadap Kinerja Karyawan PT. Nissan Radin Inten Jakarta Timur". Skripsi. Fakultas Ekonomi. Universitas Negeri Yogyakarta.

Suyadi Prawirosentono. (1999). Kebijakan Kinerja Karyawan. Yogyakarta : BPFE Yogyakarta.

Udit Bagaskoro. (2015). "Pengaruh Gaya Kepemimpinan, Motivasi Kerja dan Komitmen Organisasi terhadap Kinerja Pegawai Pengelola Keuangan di Universitas Negeri Yogyakarta”. Skripsi. Fakultas Ekonomi. Universitas Negeri Yogyakarta.

Umarudin Aziz. (2015). "Pengaruh Budaya Organisasi dan Kepuasan Kerja terhadap Kinerja Karyawan RRI Yogyakarta”. Skripsi. Fakultas Ekonomi. Universitas Negeri Yogyakarta.

Utami Tunjung Sari. (2014). "Pengaruh Kompensasi dan Gaya Kepemimpinan terhadap Kinerja Karyawan Melalui Motivasi Kerja Karyawan CV. Terus Jaya Cilacap". Skripsi. Fakultas Ekonomi. Universitas Negeri Yogyakarta.

Yoga Aprilianingrum. (2015). "Pengaruh Motivassi Kerja dan Disiplin Kerja dan Pengalaman Kerja terhadap Produktivitas Kerja Karyawan pada Industri Mebel di Temuwangi Pedan Klaten Jawa Tengah". Skripsi. Fakultas Ekonomi. Universitas Negeri Yogyakarta. 